\title{
There is value in taking the time to teach history of dentistry and ethics in dentistry curriculum
}

\section{[Diş hekimliği müfredatında diş hekimliği tarihi ve etik eğitimi için zaman ayırmanın önemi]}

https://doi.org/10.1515/tjb-2017-0094

Received February 8, 2021; accepted April 3, 2021;

published online September 9, 2021

\section{Abstract}

Objectives: The teaching and assessment of soft skills such as ethical behaviour remains a challenge to dental schools. This paper aims to attempt to help the description and retrospective evaluation of a history of dentistry and medical ethics course in the dentistry curriculum of Cyprus Health and Social Sciences University.

Methods: The study included students $(n=78)$ of the Faculty of Dental Sciences of Cyprus Health and Social Sciences University. History of dentistry and medical ethics are taught each for $1 \mathrm{~h}$, total $2 \mathrm{~h}$ per week in the curriculum (theoretical/cases). Students' academic performance was evaluated with mid-term and final exams. Participants were assessed according to their level of success and failure.

Results: Participants of the study were $51.3 \%(n=40)$ male and $48.7 \%(n=38)$ female students. The success rate of the midterm exam was $78.34 \%$, while the success rate of the final was $76.32 \%$. Mid-term exam success was not statistically significantly different than final exam ( $p>0.215)$.

\footnotetext{
*Corresponding author: Aylin Sepici Dinçel, Department of Medical Biochemistry, Faculty of Medicine, Gazi University, Ankara, Turkey, 06510, E-mail: asepicidincel@gmail.com. https://orcid.org/00000001-5847-0556

Erdal Ergünol, Department of Oral and Maxillofacial Surgery, Faculty of Dentistry, Cyprus Health and Social Sciences University, Güzelyurt, TRNC. https://orcid.org/0000-0002-7044-7524

Rabia Şemsi, Department of Medical Biochemistry, Faculty of Medicine, Gazi University, Ankara 06510, Turkey. https://orcid.org/ 0000-0002-8477-5537
}

Conclusions: The success of our students in the history of dentistry and ethics course are promising clues for us to propose that there is value in taking the time to teach the course in dental curriculum.

Keywords: academic achievement; education; history of dentistry; medical ethics; qualitative research.

Öz

Amaç: Etik davranış gibi hassas becerilerin öğretilimesi ve değerlendirilmesi diş hekimliği fakültelerinde önemlidir. Bu makale, Kıbrıs Sağlık ve Toplum Bilimleri Üniversitesi diş hekimliği müfredatında yer alan diş hekimliği tarihi ve tıp etiği dersinin tanımlanmasına ve geriye dönük olarak değerlendirilmesine yardımcı olmayı amaçlamaktadır.

Gereç ve Yöntem: Araştırmaya Kıbrıs Sağlık ve Toplum Bilimleri Üniversitesi Diş Hekimliği Fakültesi (n=78) öğrencileri dahil edildi. Müfredatta diş hekimliği tarihi ve tıp etiği 1'er saat olmak üzere, haftada toplam 2 saat ders verilmektedir (teorik/vakalar). Öğrencilerin akademik başarıları, ara sınav ve final sınavları ile değerlendirildi. Katılımcılar başarı ve başarısızlık düzeylerine göre değerlendirildi.

Bulgular: Araştırmanın katılımcıları \%51.3 (n=40) erkek ve $\% 48.7(\mathrm{n}=38) \mathrm{k}$ ż öğrencidir. Ara sınav başarı oranı \% 78.34, final başarı oranı ise \%76.32'dir. Ara sınav başarısı, final sınavından istatistiksel olarak anlamlı bir farklılık göstermemiştir ( $\mathrm{p}>0.215)$.

Sonuç: Öğrencilerimizin diş hekimliği tarihi ve etik dersindeki başarıları, diş hekimliği müfredatında yer alan dersi öğretmek için zaman ayırmanın değerli olduğunu önermemiz için umut verici ipuçları vermektedir.

Anahtar Kelimeler: akademik başarı; eğitim; diş hekimliği tarihi; tıp etiği; nitel araştırma. 


\section{Introduction}

The profession of dentistry includes an intertwined science and art applications. Science is interested in what can be observed and measured, and a good dentist knows well about the symptoms of oral diseases and how to treat them. Nevertheless, scientific dentistry has its limits, notably in the matter of human individuality, rights, responsibilities and culture [1]. The art of dentistry includes the implementation of dental science and technology to the patients in communities. In the recognition and the administration of these arts, humanities and social sciences play an important role in conjunction with ethics [2].

Dental practice deeply includes ethics as its intrinsic component. Although dental ethics is also related to bioethics, it is not exactly identical. Though dental ethics focuses firstly on issues arising in the practice of dentistry, it is the field of ethics that develops through the examination of the comprehensive problems caused by the developments occurring in bioethics, medicine and biology, and the scientific results that depend on various technological developments on the ethical level $[3,4]$. However bioethics differs from dental ethics as it does not require the acceptance of certain values that are specific to the health care practice. Dental ethics merely means moral duties and imperatives of the dentists to the patients, to the society and to their professional colleagues. It evaluates how we should act best in the light of our duties and possessive as moral agents. Among the variety of ethical issues in dental practice, the most important ones may include: compassion, competence, medical error, autonomy, confidentiality and patient/ dentist relationships [5].

Principally, code of ethics was mainly developed for patient's benefit and it represents principles of professional conduct such as responsibilities and rules to which the dentist must obey not only in regard to patients but also to the society and colleagues. Code of Ethics are given in Figure $1[6,7]$. The Association for Dental Education in Europe (ADEE) identified the necessary hard (scientific and clinical competence and technical proficiency) and soft skills (social skills, personal values and ethical behavior) that future dentists in Europe ideally should obtain. At the same time, the teaching and assessment of soft skills is really a putative challenge to dental schools. Related with the developments in molecular bioscience, the curriculum gets

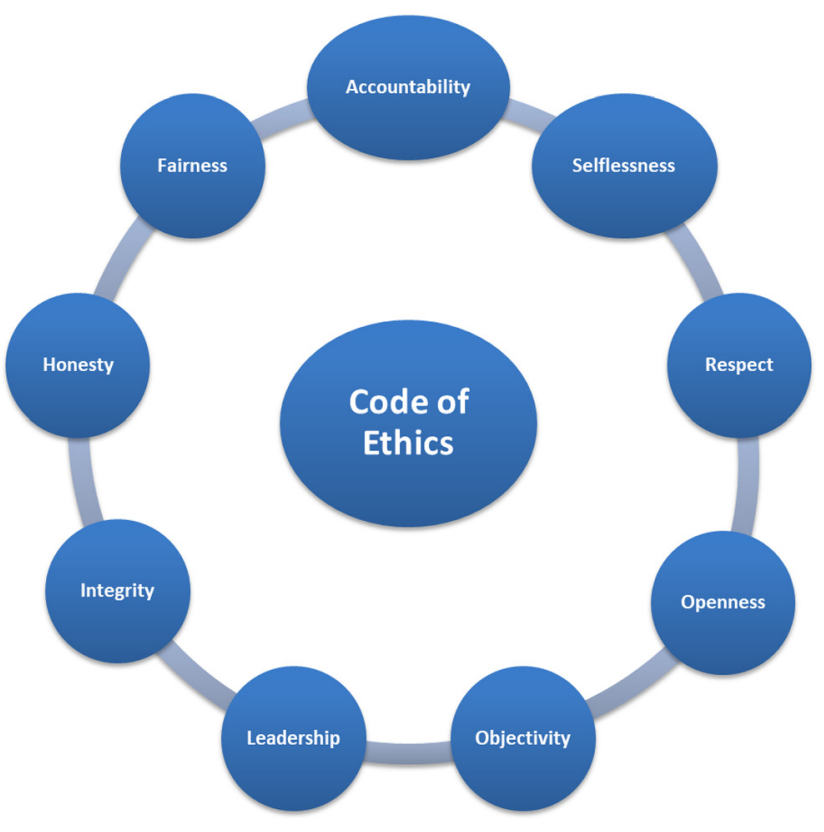

Figure 1: Code of Ethics.

more crowded, and there is not enough time to fit in discussion of ethics as well [8].

Dentistry is one of the oldest medical professions, dating back to 7000 B.C. and many of the remarkable techniques used today can be traced to the very earliest of times in every culture. As B.W. Weinberger wrote in 'Dentistry: An Illustrated History', "A profession that is ignorant of its past experiences has lost a valuable asset because "it has missed its best guide to the future."”

Thus it is very important that dentistry students learn the history of their profession along with the ethics that developed within this rich history.

This paper evaluates how the history of dentistry and ethics course is given and assessed in a new private university.

\section{Materials and methods}

History of dentistry and medical ethics courses are given each an hour per week in the first year dentistry curriculum. The courses were taught by Erdal Ergünol and the teaching strategy included both theoretical lectures and related cases. General features of the course and learning objectives are given in Table 1.

Attendance is mandatory by $80 \%$ and the assessment is conducted with mid-term and final exams which contain MCQ and T/F questions. The academic success is determined by a minimum of $70 / 100$ points.

This is a retrospective study which evaluated the mid-term and final exam results of students in $2018(n=78)$. All related demographic data of the students were obtained. 
Table 1: General features of the course and learning objectives of History of dentistry and medical ethics courses.

\begin{tabular}{|c|c|}
\hline Course name & History of dentistry and ethics \\
\hline Instructor & Assistant Professor Erdal Ergünol \\
\hline $\begin{array}{l}\text { Course hours per } \\
\text { week }\end{array}$ & $1 \mathrm{~h}$ each (total $2 \mathrm{~h}$ ) \\
\hline Learning objectives & $\begin{array}{l}\text { To understand the history of dentistry, } \\
\text { Describe the key events in dental history } \\
\text { (ancient origins, middle ages, 18th and 19th } \\
\text { century developments, innovations in tech- } \\
\text { niques and technology in the 20th and 21st } \\
\text { century) } \\
\text { To have knowledge about making evaluations } \\
\text { about the future of dentistry, } \\
\text { Matters to be considered in the consultation, } \\
\text { To be aware of subjects that are incompatible } \\
\text { with physician, present correct behavioral } \\
\text { models to physician candidates by addressing } \\
\text { issues such as medical deontology regulation } \\
\text { and physician oath }\end{array}$ \\
\hline Teaching strategies & Teacher-centered method \\
\hline $\begin{array}{l}\text { Assessment } \\
\text { techniques }\end{array}$ & Mid-term and finale exam \\
\hline
\end{tabular}

\section{Statistical analysis}

When evaluating the findings obtained in this study, statistical analysis for IBM SPSS Statistics 18 (IBM SPSS, Turkey) programs were used. Conformity of parameters to normal distribution when evaluating study data Shapiro Wilks test was used to determine the normal distribution of the parameters. Descriptive statistical methods, that is, mean, standard deviation and frequency were determined in the study data. In the comparison of qualitative data, paired t-test was used. Statistical significance was evaluated at $\mathrm{p}<0.05$.

\section{Results}

The age range of the study group was 19-31 (21.41 \pm 3.33$)$ years, while the female/male ratio was $48.7 \% / 51.3 \%$. The educational backgrounds of students indicate that $55 \%$ of them were graduated from normal high school, $29.62 \%$ from private and science high school, $7.96 \%$ from vocational high schools and $7.42 \%$ were from Anatolian High School. The academic success rate of the midterm and final exams $(78.34 \%, 76.32 \%$ respectively) were shown in Figure 2. In the $95 \%$ confidence interval, there is no statistically significant difference between midterm and final success ( $p>0.215$ ).

When the academic success was compared to one of the basic science subjects, "biochemistry", the average success rate of history of dentistry course was significantly higher $(p<0.001)$. The average and standard deviation values of grades for biochemistry and history of dentistry and medical ethics courses of the Term I students were $46.9 \pm 10.3$ and $87.7 \pm 10.4$, respectively. A statistically significant difference was found between the success of Term I students in biochemistry and history of dentistry and medical ethics course.

The evaluation of mid-term and final exam questions showed some interesting features. Some questions and the correct/false answer ratios are given below:

Multiple Choice Question - "Who makes teeth shots in India with special metal tools similar to modern cases?" Answer - 51.28\% correct, $48.72 \%$ wrong

True/False Question - "The relationship between the physician and the patient is based on trust and the

\section{Mid-term}

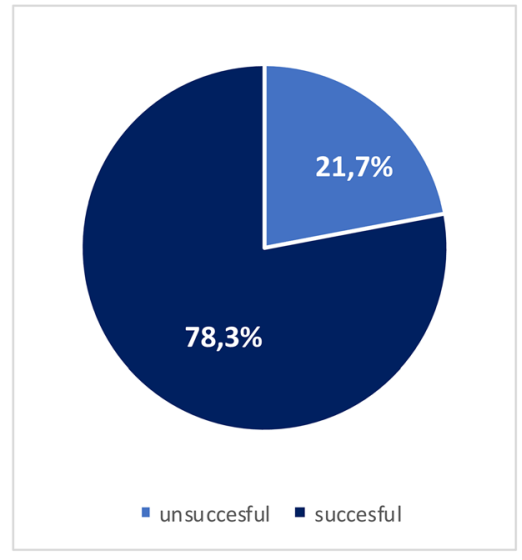

Finale

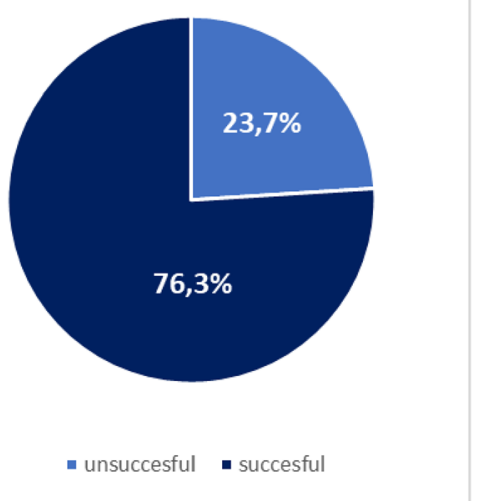

Figure 2: The midterm and finale exams results off Term 1 students. 
physician is obliged to keep the patient's secrets" Answer $100 \%$ correct

Multiple Choice Question - "Who is the greatest philosopher and physician of the Islamic world, the author of the most well-known book of all time, Qanun?” Answer$100 \%$ correct.

Multiple Choice Question - "In which century emerged the need to establish a supervisory mechanism on physicians with the establishment of universities in Europe and the introduction of systemic medical education?” Answer $67.95 \%$ correct, $32,05 \%$ wrong

\section{Discussion}

This is a preliminary study that shows how a history of dentistry and ethics course is run at the Faculty of Dentistry of Cyprus Health and Social Sciences University.

The retrospective comparison of the academic success of dentistry students indicates a remarkable higher success for history of dentistry and ethics course compared to a basic science course (Biochemistry).

The practice of dentistry requires dentists to exemplify compassion, competence and autonomy values to a higher degree than in other occupations $[9,10]$. Serving in a profession in health field, dentists have to understand and empathize with the patients' values, emotions and concerns. Patients can respond better to treatment if they perceive that the dentist appreciates their concerns and treats them as a whole rather than just their illness.

Dental students undergo a fairly long professional training during which they also gain technical skills in the clinical environment. The close interactions with patients also require basic knowledge about ethics so that the dentists of the future can exhibit professional behaviour and attitudes.

New ethical issues arise with changes in dental practice because of social and political environment. Dentistry has been governed by a stationary self-regulating bodies as dental associations [10]. These professional bodies are responsible for ensuring high ethical and legal standards for the profession.

Not only the daily practice, but the scientific and clinical research in dentistry also requires knowledge and training in ethics. Scientific studies have to strongly adhere to ethical principles. In their study of awareness of healthcare ethics, Hariharan et al. showed that approximately $13 \%$ of the students had no idea of the content of the Hippocratic Oath contain and were not aware of the presence of the institutional ethics committee [11].
Earliest evidence in the history of dentistry dates back from $7000 \mathrm{BC}$ to $5500 \mathrm{BC}$ which indicates that it is almost as ancient as the history of humanity and civilization. Dental history is not simply about the technological advancements made within the field and mechanics, but also rather about the personalities of dental professionals. Their interests and passions have an impact upon dental history as the performance of dental work itself [10-12]. Sadly, most of the dental curriculum in different countries do not include the history of dentistry course. However, there is richness present in the profession history waiting to be explored, investigated, rethought, reanalyzed, and applied to present day situations. Dental students should be introduced to this richness to develop belonging to their professional community and to promote it further. Dentistry faculties should not only offer adequate instructions to student but also should be encouraged to develop historical collections.

\section{Conclusions}

Studies examining the status and role, the delivery and assessment of the teaching of history of dentistry and ethics in the dental undergraduate curriculum, as well as the space that it is given in the curriculum are important. However, it is important that these subjects are not isolated to classroom lectures but also include "hands on discussion of ethical dilemmas and scenarios". Teaching the history of dentistry and ethics to dental students can positively influence their sense of belonging to the discipline and improve their ethical conduct as dentists. We had the privilege to observe the success of our students in the history of dentistry and ethics course which can be promising clues for us to propose that "there is value in taking the time to teach the course in dental curriculum".

\section{References}

1. Ethical Decision Making. Ethics Hand Book for Dentists. American College of Dentists USA; 2013:18-21 pp.

2. Kadıoğlu FG. Overview of dentistry ethics. Hacettepe Univ Med J 2009;40:120-4.

3. Dental Ethics Manual, FDI World Dental Federation 2007.

4. Arda B. Conceptual introduction and basic approaches to ethics. In: Arda B, Kahya E, Başağaç Tamay G, editors. Ethics and History of Science. Ankara: Ankara University Printing House; 2004: 21-36 pp.

5. Alpay S, Kadıŏlu FG, Oral M, Ozer MZ, Sakallığlu U, Sert G, et al. Rules of Professional Ethics of Turkish Dentists. Ankara: TDB Publications; 2013.

6. Principles of Ethics and Code of Professional Conduct. Chicago: American Dental Association. Revised January 2003. 
7. Beauchamp T, Walters K, Shaw M. Medical Ethics: Contemporary Issues in Bioethics and Managerial Ethics. Stamford: Cengage Learning; 2008.

8. Brennan M, Oliver R. Ethics \& Law for the Dental Team. Lancaster: Carnegie Books; 2006.

9. Ozar DT, Schiedermayer DL, Siegler M. Value categories in clinical ethics. J Am Dent Assoc 1988;116:365-8.
10. Hakeri H. Diş Hekimlerinin Yasal Sorumlulukları. Sağlık Hukuku Digestası 2009;1:19-27.

11. Hariharan S, Jonnalagadda R, Walrond E, Moseley H. Knowledge, attitudes and practice of healthcare ethics and law among doctors and nurses in Barbados. BMC Med Ethics 2006;7:E7.

12. Görkey Ş. Hasta hakları. (Yay. Haz. Hatemi H, Doğan H.) Medikal Etik -4. İstanbul Yüce Yayım; 2003, vol 10. 